Dorota RUDNICKA-KASSEM

Jagiellonian University in Kraków

e-mail: d.rudkass@interia.pl

\title{
SEARCHING FOR A NEW IDENTITY: MUSLIMS IN WESTERN EUROPE
}

ABSTRACT This article is devoted to the issue of multi-ethnic relations in Western Europe, and in particular to the question of the search of Muslim nowadays identity. The so-called civilization clash, language and culture diversity, the ongoing debate about the Muslims both new comers and old settlers are the crucial issue. Muslims in Western Europe are in constant search for their new identity made out of various elements, such as influences of home tradition, new movements, including fundamentalism and modern western trends. What is more, since Europe is predominantly Christian country, a development of Muslim-Christian dialogue is essential because it will have a tremendous influence of shaping new Muslim identity.

Keywords: Muslims, Western Europe, newcomers, identity, family reunion, transition new data 
$\mathrm{O}$ ne may say that people who decide to leave their native land and emmigrate to another country are usually very determined because the very hard and often tragic conditions of their lives prompted them to take such a decision. However, in their new country they experience new challenges and the encounter with a different culture, language and customs usually contributes to the increasing feeling of alienation and uncertainty. Eventually, as a result, their situation, at least for some time, does not change for better. Having problems with communication, struggling with day-to-day problems, the immigrants put themselves in a situation which they cannot fully understand. They not only have to learn how to "survive" in this new environment but, at the same time, they have to remember who they are and where they came from. In other words, while adjusting to their "new" and very "different" world they have to preserve their identity and protect themselves from losing its essence and values.

The Second World War (1939-1945) caused a tremendous destruction in Europe. Some cities practically disappeared, in the others many living quarters, historical monuments and industrial sites were substantially destroyed. As a result the social, political, economic and cultural life in the continent was no longer the same. Europe needed total reconstruction and this could not be done without a large quantity of cheap labor force. Between 1950 and 1970 the first waves of immigrants came to Europe, especially to Great Britain and France and then, during the 1950s to Germany and other countries. These waves, followed by subsequent ones, were to form the bulk of the immigrant populations in Western countries.

Among these immigrants there were also Muslims, and between 1950 and 1970 a number of them significantly increased. It was no longer the issue of a few thousand workers that the host country had to deal with but rather of several hundred thousands of Muslim residents who were simply living in European countries, establishing families and the old intention of going back to their native lands was becoming a rather remote hope. Instead the Muslim immigrants were making plans for their future in Europe. ${ }^{1}$

It is now more than a generation since Western Europeans began to notice that there were Muslim communities settling in their cities. The days of the temporary migrant workers had been replaced by the establishment of families in a process which clearly going to be permanent. Furthermore, this fact has also reminded the Europeans that there were already well-established Muslim communities in the parts of South Eastern Europe.

The wave of immigration of people from Muslim countries which started after the Second World War brought to Europe first Muslim men, then their wives and the whole families. Although reluctantly, the European governments attempted to respond to the needs of new settlers by designing some kind of social and educational programs that would foster assimilation/integration process. As a result, the early simplistic plans that with the passage of time, perhaps over one generation, and the new immigrant communities would have become assimilated and integrated, did not work. In addi-

For complex discussions on related issues refer to: HAdDAD 2002; Cesari/McLoughlin 2005; PęDZiwiatr 2007; Parzymies 2005. 
tion, one should point out that the Europeans were and still are reluctant to accept people who were/are different, except when on their terms. This attitude has certainly contributed to Muslims' assertion of their own distinctiveness in response (see: RAMADAN 2001: 269). Furthermore, the Muslims' attachment to their tradition has forced local communities, politicians and academics in European countries to take their needs seriously and forget about naive assimilationist scenarios.

The new environment that the Muslim immigrants found in the European countries had also significant implications on them and new generations born in Europe. Therefore, they had to pay considerable attention to the impact of their new situation for their faith and its practice, and the ways in which the faith might continue to form an appropriate and functional foundation for their daily lives. In other words, while living in a modern Western environment and at the same time coping with their changing traditional background, not only they had to preserve their Muslim identity but also to "enrich" it with a European context. Aware of this new situation and pushed by the desire to protect their identity, some Muslim began to organize their communities, establishing more mosques and founding Islamic organizations in order to secure for an average person places to pray, gather, learn and to facilitate the participation in various activities of local Muslim community.

There are some important facts about Muslim presence in Europe today. Since the 1950's, their number has significantly increased and there are about 15 millions of Muslims living in Western Europe (KLAUSEN 2005). ${ }^{2}$ Muslim presence in Europe is quite visible, their religion accounts for the second one in some countries (for example in France) (see: HUNTER 2002). Many of Muslims have taken European nationality and engaged themselves in professional activity, have established businesses and participate in various professional associations and religious organizations. The number of Muslims in Europe has steadily increased due to high birth rate, family reunions and newcomers obtaining a refugee status. There are also numerous converts to Islam, who, along with the young generation of Muslims who have now became European, are at home in Europe. In addition, there is a substantial number of Muslims coming to Europe for temporary stay - to study and work.

One can notice that over the past two decades the reality of the Muslim presence in Europe has changed. There is a revival of Islamic spirituality and practice as well as a feeling of belonging to a religious community amongst a great many young Muslims either born or living in Europe. As a result the number of places of worship has multiplied. There is also a growing number of Islamic organizations, among them active cultural centers. In countries with large Muslim minorities such as France, Great Britain and Germany there are over a thousand official Islamic organizations.

With regard to the present situation of Muslims in Europe it is important to note that the overall assessment is quite positive and optimistic. One may agree with Tariq Ramadan that Muslims are generally allowed to practice their religion in peace, to build

With the illegal immigrants the number of Muslims living in Western Europe is estimated at about few millions more. 
mosques and to establish Islamic organizations due to the fact that the various European constitutions and laws respect Islam as a religion and Muslims as believers (RAMADAN 2002: 121-122).

When it comes to the expression of Muslim identity, one should bear in mind that "being Muslim" may be manifested in three ways, namely ethnic, cultural and religious. In other words within Muslim communities around the world, including Europe, one may distinguish three different types of communities. First, there are groups of "ethnic" Muslims whose members are not practicing Islam but were born in Muslim families, have Muslim names and have knowledge of important elements of Muslim religion and culture but they are more attached to their ethnic tradition. ${ }^{3}$ Second, there are groups of so called "cultural" Muslims who are considered more aware with regard to the issue of the universal dimension of Islam. They are attached to Islamic culture rooted in religious symbols. The members of such groups may differ in political views but they are bound together by strong cultural ties. Finally, there are groups of so called "religious" Muslims who are characterized by strong feeling of belonging to their Muslim 'umma. They pray five times a day and fulfill other religious requirements and duties. Some of these Muslims follow more spiritual, mystical path and join sufi orders. Others, who believe their duty is to spread the message of Islam and search for new believers, engage themselves in missionary activities and become members of various Muslim organizations. There are also Muslims who believe that Islam is not only a universal religion but also a social and political system adequate for all the people. They are often involved in Muslim fundamentalist organizations. These groups are primarily responsible for the negative image of Islam in Europe. ${ }^{4}$

While discussing the question of European-Muslim identity it is worth noting that nowadays the Western way of living does not only mean a specific attitude, namely distinctive features in peoples' behavior. The issue is more complex because, as Ramadan pointed out:

Western civilization with its machinery of values is armed with such a powerful means that it makes it difficult for anyone living in Europe to define what he or she is or is not. The media, popular culture, music, the cinema and advertising serve as vehicle to diffuse the concepts of individual and society, freedom and morality, entertainment and duty. Without warning, these concepts take root in the hearts and minds of individual, if they do not subjugate him completely, and make it difficult to determine what is really from him, of his own volition, and what is due to external contributions or influences (RAMADAN 2002: 2).

For Muslim immigrants the Western secular context often becomes confusing due to the fact that their culture is based on social values and duties while the environ-

For a few reflections on Islam as ethnicity refer to: SAYYID 1997: 38.

4 For a thorough discussion on the distinctions between Islam and the politically based fundamentalist movement known as Islamism, including the issues, such as the Islamists' reinvention of jihadism as terrorism, their confusion with the concepts of authenticity and cultural purity and the Islamism as a totalitarian ideology. See Tiвi 2012. 
ment they have chosen for their new home promotes freedom and autonomy. It is natural that some features of Western culture are quite attractive for Muslim immigrants. ${ }^{5}$ However, they should protect themselves from the "unwanted" acquisition of Western models of behavior and from the hasty admiration of Western values.

As for the first generation of immigrants, mainly unskilled workers with a poor knowledge of Islam, it was relatively easy to "protect" themselves and their families by means of a whole series of rules, interdictions or prohibitions. In this way they were "explaining" Islam within the framework of a specific relation of protection from an environment which was perceived by them as too permissive and even hostile. As a result, despite the fact that their "protective rules" sometimes were confusing, had little connection to Islam and were rather linked to their native tradition, the first generation of immigrants from Muslim countries remained strongly attached to their religion and had a feeling of their firm Muslim identity.

For those born and brought up in Europe the problem of their Muslim identity is more complex. Many of young Muslims living in European countries are often not fluent in the language of their parents and their knowledge of both the native tradition and the religion of Islam seem to be weak. How to help these young people to find and understand their roots? How to reconstruct the sense of preserving their Islamic tradition in the modern, secular context? And finally: How these new generations of Muslims born and brought up in Europe could find consciously and freely shape their own way and their own unique European-Muslim identity?

While discussing the issue of Muslim identity and means of protecting it in Western environment, one may agree with Ramadan that Islam "before being a means of protection" should be considered as an affirmative faith which "carries within itself a global understanding of creation, life, death, and humanity." (RAMADAN 2002: 3) Therefore, for today's Muslims in order to search for their "new" Islamic identity it is necessary to grasp the essence of this global vision of what the Islamic faith is (see: DoNOHUE 1983: 48-61). In other words, it is important that Muslim scholars undertake the task of explaining to people not only the essential principles of the faith, but first of all make them understandable in the light of new context within European society. What is the essence of Muslims identity? What does it mean to be a European Muslim?

Defining a Muslim identity of a person living in Europe is a complex issue and it requires taking into consideration a number of factors. As previously mentioned, a "being Muslim" can be manifested in three ways, namely ethnic, cultural and religious. However, the essence of the Muslim identity is the saying of the shahäda (profession of faith), a testimony that one believes in God and His last messenger Muhammad (SCHIMmel 1992: 34). The shahäda, the first pillar of Islam also initiates a specific way of life for both an individual and a society. A Muslim first belongs to God and this influences all spheres of his life. The individual recognition of the shabäda and the recognition of the family as the first environment of social life are the basis for entering other social relations. While practicing their religion, Muslims are called upon to face

For some remarks on related issues see: RAMADAN 2001: 267-268. 
the community dimension of Islamic way of life. ${ }^{6}$ The other four pillars of Islam, namely, the salät (prayer), the zakät (almsgiving), the sawm (fasting) and the hajj (pilgrimage) confirm and reinforce the community feeling. Therefore, for a Muslim to practice religion also means to be a member of Muslim 'umma (community). As Ramadan says:

This (social) dimension is inherent in the Islamic Faith and way of life which, in return, are both strengthened, shaped and directed by this community feeling: All Believers are but brethren reads the Qur'an (49:10). Whenever Muslims live we witness the birth of a community first created and based on common Prayer and the prescribed acts of worship and then growing, as the Muslims start to think of and actually set social activities around the mosque or through the medium of other Islamic Institutions (RAMADAN 2002: 157).

In conclusion, one may say that shahada, which is the essence of the Muslim identity together with other four pillars of Islam, upholds community sentiments and determines the social dimension of the Islamic way of life.

What does it mean to be a European Muslim? In other words: How to preserve the essence of Muslim identity in Western context?

There is an agreement among the 'ulam $\vec{a}$ (religious scholars) which stipulates that it is non-permitted for a Muslim to stay in non-Muslim environment in three cases:

a) without a determined need or a clear objective justifying the stay; b) when the settlement is based only on a selfish will (getting a good job or more money for example) or desire to follow a Western way of life while neglecting Islamic religious prescriptions; c) if the Muslim itself allies himself with non-Muslims for the purpose of fighting Islam or other Muslims (RAMADAN 2002: 166).

It is evident that in all other cases, such as working, studying, trading, establishing businesses, cooperating with local entrepreneurs, securing better future for their families, fleeing from persecution, a Muslim is allowed to stay in non-Muslim environment. However, in order that such a stay will be in agreement with the principles of Islam, two essential conditions have to be fulfilled, namely that (1) a Muslim should be free to practice his/her religion and (2) his/her would make all his/her best to work for the benefit of the entire community and contribute to its development by his/her work, study and all kinds of other activities including social, political and cultural engagements.

To be Muslim anywhere in the non-Muslim country in the world means primarily to strife to be a better person and to experience and develop the feeling of belonging to 'umma.' Furthermore, according to the Qur'an, every Muslim is individually invested with the common responsibility to bear witness to the Message before all mankind:

Thus have We made you

An Ummah justly balanced,

For a discussion on the communal solidarity of Muslims see: RAMADAN 2001: 247-248. 
That ye might be witnesses

Over the nations (THE QUR'An 1989: S: 2, v: 143, p. 58).

Thus duty of a Muslim is to spread this message to his children, to the members of his community and to the others. No matter where the Muslims are (in this case Europe) they are called upon to defend and spread justice, solidarity and values pertaining to honesty, generosity, brotherhood and love, that is, they are called upon to defend human dignity in every circumstance towards Muslims and non-Muslims. Therefore, it would be contradictory to Islamic principles for a Muslim living in the in Europe to act against the existing laws and rules.

As already mentioned, the fact that the number of Muslims in European countries has increased in recent years, as did the sudden awareness of their presence caused by their social visibility, that there are now millions of the followers of Islam residing in Europe and that almost half of them are already citizens, has created various problems, and provoked contradictory reactions among the indigenous population.

It should be pointed out that Muslims coming to Europe after the Second World War experienced three basic diverse models of integration/assimilation process, namely the German, the French and the British.

The characteristic feature of the German model was the initial assumption of the majority of the society that the post-Second World War Muslim immigrants were only temporary settlers who would come to work and after a period of time would return, with substantial savings, to their native country (see: GERMANy 2005: 32-37). However, as usual, real scenarios proved to be different and the majority of Muslim immigrants decided to stay. The German government had to face an unplanned situation and invent some kind of a program in order to help Muslim immigrant to integrate with the German society, and make important changes in the legislation to enable them to obtain important legal rights and privileges.

The French assimilationist model is based on the concepts of liberty, equality, fraternity and individual freedom that were expressed in France during the Revolution in the late $18^{\text {th }}$ century (1789-1799) (see: FranCE 2005: 21-31). The French believe that the people who form their nation are not necessarily related by blood and that their unity should be based on the acknowledgement of the same universal values. The French secular ideal of life also guarantees freedom of belief and life philosophy. However, this freedom is limited to the private sphere and the manifestation of religious differences in public is not permitted. It should be pointed out that the French assimilationist model offers Muslim immigrants many advantages, including anti-discriminative law system and relatively liberal regulations of acquiring the French citizenship. However, the most important is the well-organized system of public education. The aim of this system is to instill the republican ideals and values in students, eliminating the emphasis on ethnic, religious and social differences. It is worth noting that free access to education at all levels is also provided for the children of illegal immigrants. Despite all these quite advantageous policies, the French assimilationist model does not protect immigrants from discrimination, alienation and anti-Muslim slogans and actions of radical nationalist groups. 
As for the British model, it does not focus on full assimilation with the society but promotes the policy of multiculturalism which is based on reciprocal tolerance and enables the immigrants to retain their cultural identity, that is to express their ethnicity and religious beliefs (see: The United Kingdom 2005: 10-19). The idea of multiculturalism is linked with the historical process of forming the British nation from different other nations, such as English, Scottish, Welsh and Irish and a large wave of immigrants from all part of the world during the post-Second World War period.

In Great Britain immigrants are considered an ethnic minority and the integration policy, adopted by the government, focuses on the promotion of tolerance and attempts to eliminate discrimination. Liberal economy promotes individual initiatives and enables the immigrants to participate actively in job market. Furthermore, immigrants are relatively free concerning the observance of their tradition and religious practices. In contrast to the French model, the educational system in Great Britain is not centralized, and therefore the schools are not playing important role in promoting integration and universal values. Although relatively advantageous for the immigrants, British policy of multiculturalism is criticized because it contributes to the separation of ethnic minorities from the society.

Over the last two decades these three patterns evolved and a number of diverse programs were designed in order to facilitate the integration/assimilation process of Muslim minorities with indigenous European societies. Politicians and activists have attempted to address the problem by designing various strategies to help the integration processes while the sociologists reflected on old concepts related to the minority issues and proposed a typology of possible approaches. It seems that the three patterns, namely the three concepts of reference that exist today are similar the three basic models discussed previously. The present-day patterns are: (1) the assimilationist model which supposes a total amalgamation between the Muslim and the Western cultural way of living, (2) an isolationist model which is based on the preservation of identity through the creation of an organized religious and cultural community within the global society and (3) the middle way model, i.e., the integrationist model that should provide both a protection to Muslim identity and an individual status of citizenship (like indigenous people). There is still confusion concerning these concepts and there are debates on more efficient integration strategies that help Muslim minorities to cope with everyday life in European countries. However, one may say that the middle way pattern should be the best solution.

For the last four hundred years the predominantly Christian European societies have gone through a very deep process of secularization. One may say that as a result the issue of faith, religion and practice is limited to a private sphere and no longer plays such an important role in social life. In the recent years there is even a fear of progressive atheism because Europeans are no longer used to a public manifestation of religious beliefs in their everyday lives and in great majority, either not practicing their religion much or not practicing it at all (John PAUL II 1995).

For a through discussion see: RAMADAN 2002: 179-195. 
Since for Muslims Islam means not only faith, religion and practice but also embraces all the aspects of their lives, it seems quite natural that in secular European societies they would face two choices, that is between (1) adopting the dominant trend of indigenous people, i.e., to limit the issue of religion to personal intimate dimension and (2) isolating themselves, i.e., to live in Europe out of Europe. ${ }^{8}$ However, for Muslims none of these choices proved to be the appropriate ones.

It is true that for a great number of Muslims living in the Western countries and even in the Middle East and Asia, to be a part of today's modern global society means to adapt themselves to the Western way of life. Since the days of Muhammad 'Abduh' many Muslim thinkers argue that Islam is a universal message that needs to be "modernized." In other words the prescriptions of Islam have to be rethought and actualized by giving expression to the modern progress in all spheres of life (see: ARKoun, Mohammed 1994). It seems as if for a modern Muslim living in Europe the choice should be obvious, and, that there is no alternative: to be progressive, open-minded and modern and to be "relatively" European means to "rethink Islam" in such a way that Muslim identity would fit the Western environment. However, as Ramadan underlines, the majority of European Muslims still seem to do not pay much attention to the issue of "modernization" of their minds and "neglect or even ignore both the internal dynamic of Islam and the nature of Muslim identity." (RAMADAN 2002: 185) One may say that although the process of acculturation "helping" Muslims to embrace the Western way of life seems to be irreversible, it is not natural and efficient as predicted. Despite the fact of relative integration and involvement in social, political and cultural life as indigenous population, Muslims of the second and third generation hardly forget their Islamic identity, even though they do not practice their religion.

Many Muslims try to avoid being absorbed into European societies by focusing on community life. Some groups, for example from India or Pakistan, gather in a chosen area in attempt to reproduce a social microcosm, a reminiscence of their native social environment, within which they live among themselves with few contacts with indigenous population or society as a whole. Their aim is to be in Europe but "at home." It is quite often that within such communities one may find young people from second or third generations who cannot speak English or French properly despite the fact of being born in Great Britain or France. For example, these are the cases of young girls who are treated as if they still were in their native countries of their parents and who are frequently denied the opportunity to acquire good education (RAMADAN 2002: 187). It is true that Western environment has important influence on the values, fashions and behavior; especially for Muslim youth and that there is need for new educational programs that would help them to cope with the clash of their native tradition and nowadays Western trends. Therefore, while considering all these dangerous influences, many

For a thorough discussion see: RAMADAN 2002: 182-187.

9 Muhammad 'Abduh (1849-1905), was one of the most famous reformers of Islam from Egypt. He called upon the Muslims to reconcile Western modernity with the tradition of Islam and undertook the task of reforming the teaching at $\mathrm{Al}$-Azhar, the most famous Islamic university. For a recent study refer to: Haj 2009. 
Muslims still believe that by isolating themselves from the Western society they would protect well both their ethnic and Muslim identities.

In the twenty first century with the process of globalization getting stronger not only in the sphere of economy but also in the sphere of culture, the issue of peoples' identity has acquired even more importance. Therefore, both the assimilationist and isolationist are not the right patterns for Muslims to "adjust" to European environment because these patterns can not protect their identity. As mentioned previously, the middle way, namely the integrationist pattern seems to be the most appropriate. As Ramadan pointed out, for Muslims living in Europe nowadays it is important:

to understand who they are and what they stand for means that they are able to determine their identity per se, according to their Islamic references and no longer through the image other develop of them as if they were but objects of some alien elaboration. It is only by acting in this way that European Muslim will feel that they are subjects of their own history, accountable before God, responsible before mankind. To be subject s of their own history also means that they will eventually go beyond this pernicious feeling of being foreigners, of being different, of being an obvious manifestation of an insoluble problem (RAMADAN 2002: 189).

It is natural that for the members of the minority groups, in this case Muslims, having a clear awareness of their identity would strengthen their confidence and enable them to establish sound relations with indigenous people. Furthermore, it would help them to get involved in socio-political and cultural life of the local Western community life.

As mentioned previously, in the last few decades Muslim thinkers have been calling to "rethink," and "actualise" the prescriptions of their religion, so that Islam would give an equate expression to the modern progress in all spheres of life. There is no doubt that this "revitalization" of faith could facilitate the process of shaping a "revitalized" Muslim identity, the essence of which would be firmly grounded in Islamic sources, tradition and culture in the light of modern Western context. ${ }^{10}$ Such a "revitalized" identity would protect itself from negative influences of some aspects of the Western life style. All in all, Muslims living in Europe would feel more confident in presenting the right image of their new "European-Muslim" identity.

Ramadan mentions four elements or dimensions that form a modern Muslim identity, namely (1) faith, practice and spirituality, (2) an understanding of texts and context, (3) to educate and transmit, and (4) to act and participate (see: RAMADAN 2002: 189-195).

The most important element of Muslim identity is faith, confirmed and testified by shahāda. It naturally takes concrete form of practice, namely prayer, almsgiving, fasting, pilgrimage to Mecca. ${ }^{11}$ As the consequence of faith and practice Muslims develop their spirituality which keeps their faith alive and strengthens it. It's important to note that word "Islam" in itself means "submission" to God and spirituality is the memory, re-

10 For a thorough discussion on related issues see: SAYYID 1997: 31-49.

11 About the importance of faith and practice for Muslims, and in particular these living in the West see: Esposito/Mogahed 2007: 5-17. 
membrance and the intimate effort to fight against human tendency to forget God. One may say that the Muslim identity means primarily "a faith, a practice and spirituality." Therefore, to respect such an identity is to allow Muslims to perform all the practices that shape their spiritual life. Faith and reference to God, the idea that the sacred does not uniquely lie in rituals, but rather in any act that preserves the remembrance of the Creator in one's conscience - all these nourish the daily existence of Muslim women and men and give strength and meaning to their spirituality. In the entire Muslim world, one senses that there still remains a very strong imprint of the religious point of reference and conviction that "this life is not the only life." (RAmadan 2001: 234) Spirituality means a lot to Muslims; it makes them feel closer to God, give them strength to face upcoming challenges and cope with everyday worries and problems. Many Muslims say that spirituality and, in particular prayer, simply "nourish" their souls:

How many times do people in our comfortable society eat? Dieticians recommend three meals and two snacks... Well, Islam views the human being is not only a physical being, but a spiritual being as well, and just as our physical dimension requires regular nourishment throughout the day, so does our spiritual dimension... [five prayers] five small meals for the soul (Esposito/Mogahed 2007: 13-14).

It is worth noting that there is no true faith without understanding. For a Muslim this means to understand both the sources of their faith, namely the Qur'an and the Sunna (Tradition) and the context within which they live. In other words, as Ramadan pointed out:

The responsibility of every Muslim is based on this twofold aspect of "understanding": that is to develop, in concomitance, "an intelligence of the texts" and "an intelligence of the context" in order to find the way to remain faithful to Islamic teachings. This has been the fundamental teaching of Islamic legal practice since the time of the Prophet, unceasingly kept up by the great scholars over the centuries (RAMADAN 2002: 191).

So, it seems obvious that the Muslim identity is based on a permanent dynamic and dialectic movement between the Islamic sources and the environment. In addition, it is in a constant process of "internal" development and growth. Therefore, it "is not closed, confined within rigid and fixed principles." (RAMADAN 2002)

According to Islamic sources it is a duty of a Muslim to learn (Ramadan 2002: 192). Therefore, they should work constantly on increasing their knowledge. This knowledge is the condition of understanding not only the meaning of Islamic sources but also the surrounding world. Furthermore, such a knowledge and understanding would bring Muslims closer to God $^{12}$ and help to make right choices. All in all, the second element of Muslim identity is defined through an active and dynamic intelligence requiring knowledge, freedom and a sense of responsibility.

12 As the Qur'an says: “Those truly fear Allah, / Among His Servants / Who have knowledge." S: 35, v: 28, THE QuR'An 1989: 1109. 
The third element of Muslim identity is "to educate and transmit." As mentioned previously, it is important for Muslims to remember that their first duty concerning their children is to pass to them the amana (trust). Educating children in order to give them opportunity to receive the trust is the most important function of the parents. They should explain to the children who they are, and then the children, responsible before God, will choose their way. Subsequently, Muslims should also pass the trust to their relatives. Finally, their responsibility before God is to make the message of this trust known by explaining its contents as much as possible and to bear witness to it before mankind.

The fourth element of Islamic identity embraces Muslims' action and participation.

In other words, whenever a Muslim lives, their actions should be defined by "activity and "participation." As RAmadan (2002: 194) says:

This action, whatever the country or the environment, is based on four major aspects of human life: to develop and protect spiritual life within society, to spread religious as well as secular education among people, to act for more justice within each sphere of social, economic and political life, and finally, to promote solidarity with all types of needy people.

It should be pointed out that, as viewed in the modern European context, the elements discussed above are essential to both the development and the protection of Muslim identity in its double dimension, namely individual and social. Therefore, it appears that the definition of Muslim identity should be seen as open and dynamic, that its essence has to crystallize in constant interaction with the environment.

One may agree with Ramadan that in our modern world the most advantageous "position" for the Muslims living in Europe would be the "middle path." While remaining fully aware of the four-fold dimension of their identity, European Muslims should always be ready to participate in the life of the local communities both as Muslims and as citizens.

\section{REFERENCES}

Arkoun, Mohammed 1994: Rethinking Islam. Common Questions, Uncommon Answers. Transl. and ed. by Robert D. Lee. Boulder: Westview Press.

Cesari, Jocelyne; McLoughuin, Seán (eds.) 2005: European Muslims and the Secular State. Aldershot/Burlington, VT: Ashgate Pub. Co.

Donohue, John J. 1983: "Islam and the Search for Identity in the Arab World," in: John L. Esposito (ed.): The Voices of Resurgent Islam. New York/Oxford: Oxford University Press, p. 48-61.

Esposito, John L.; Mogahed, Dalia 2007: Who Speaks for Islam? What a Billion of Muslims Really Think. New York: Gallup Press.

France 2005: "France," in: Muslims in Europe. Integration Policies in Selected Countries. (CRS Report for Congress. Order Code RL33166.), p. 21-31. Available under <http://digital. library.unt.edu/ark:/67531/metacrs7945/m1/1/high_res_d/RL33166_2005Nov18.pdf> (accessed on August 20, 2012). 
Germany 2005: "Germany," in: Muslims in Europe. Integration Policies in Selected Countries. (CRS Report for Congress. Order Code RL33166.), p. 32-37. Available under <http://digital.library.unt.edu/ark:/67531/metacrs7945/m1/1/high_res_d/RL33166_2005Nov18. pdf> (accessed on August 20, 2012).

Haddad, Yvonne Yazbeck (ed.) 2002: Muslims in the West. From Sojourners to Citizens. Oxford/New York: Oxford University Press.

HaJ, Samira 2009: Reconfiguring Islamic Tradition. Reform, Rationality, and Modernity. (Cultural Memory in the Present.) Stanford: Stanford University Press.

Hunter, Shireen T. (ed.) 2002: Islam, Europe's Second Religion. The New Social, Cultural, and Political Landscape. Westport, Conn.: Praeger.

John Paul II 1995: Encyclical Evangelium Vitae (March 25). Available under <http://www. vatican.va/holy_father/john_paul_ii/encyclicals/documents/hf_jp-ii_enc_25031995_ evangelium-vitae_en.html> (accessed on August 20, 2012).

Klausen, Jytte 2005: The Islamic Challenge: Politics and Religion in Western Europe. Oxford/ New York: Oxford University Press.

Parzymies, Anna (ed.) 2005: Muzutmanie w Europie. Warszawa: Dialog.

PĘDZIWIATR, Konrad 2007: Od Islamu imigrantów do islamu obywateli. Muzutmanie w krajach Europy Zachodniej. Kraków: Nomos.

The QuR'An 1989: The Meaning of the Holy Qur'an. Trans. and comment. 'Abdullah Yusuf 'Ali, Beltsville, Md.: Amana Publications.

Ramadan, Tariq 2001: Islam, the West and the Challenges of Modernity. Transl. by Said Amghar. Leicester: The Islamic Foundation.

Ramadan, Tariq 2002: To be a European Muslim. A Study of Islamic Sources in the European Context. Leicester: The Islamic Foundation.

SAYYID, Bobby S. 1997: A Fundamental Fear. Eurocentrism and the Emergence of Islamism. London/New York: Zed Books.

SCHimmel, Annemarie 1992: Islam. An Introduction. Albany: State University of New York Press. TiBi, Bassam 2012: Islamism and Islam. New Haven: Yale University Press,

The United Kingdom 2005: “The United Kingdom," in: Muslims in Europe. Integration Policies in Selected Countries. (CRS Report for Congress. Order Code RL33166.), p. 1019. Available under <http://digital.library.unt.edu/ark:/67531/metacrs $7945 / \mathrm{ml} / 1 /$ high_ res_d/RL33166_2005Nov18.pdf> (accessed on August 20, 2012).

Dorota RUDNICKA-KASSEM, Ph.D., Associate Professor, a graduate of the Jagiellonian University (Arabic Philology) and McGill University (Islamic Studies), specialist on modern Islam and modern Islamic history, modern Arab thought and political theatre, in the recent years she is particularly interested in the issuee of Christian-Muslim dialogue. Her work John Paul II, Islam and the Middle East:The Pope's Spiritual Leadership in Developing a Dialogical Path for the New History of Christian-Muslim Relations addresses new developments in the history of that dialogue as introduced by the documents of the Second Vatican Council, the policy of Paul VI and John Paul II. Dorota Rudnicka-Kassem conducts courses on various issues related to Muslim civilization, including introductory ones, and more elaborated ones, both in Polish and in English. 